\title{
Foreign Exchange Inflows in Emerging Markets: How Much Are They Sterilised?
}

\author{
Michael Bleaney* and Sharmila Devadas ${ }^{\mathrm{II}, \#}$ \\ *School of Economics, University of Nottingham, UK \\ ${ }^{\mathrm{I} C e n t r a l ~ B a n k ~ o f ~ M a l a y s i a, ~ M a l a y s i a ~}$
}

\begin{abstract}
As some emerging market economies have amassed large quantities of foreign exchange reserves, concern has arisen over the sterilisation of the domestic money stock from these flows. Existing studies focus mostly on narrow (reserve) money, and estimate a high degree of sterilisation. Empirical work on the long-run relationship between money and prices emphasises broad money, yet the long-run effect of foreign exchange inflows on broad money has been almost entirely ignored. Using a sample of quarterly data from 28 countries over the period 1990-2010, it is shown that broad money is sterilised to a significantly smaller degree than reserve money, raising concerns about the implications for financial imbalances and inflation. This pattern of sterilisation is not confined to any particular group of countries and is unrelated to the nature of the flows (e.g. current account versus capital account surpluses). Sterilisation rates have increased in Asia during the recent period of persistent accumulation of foreign exchange reserves.
\end{abstract}

Keywords: foreign exchange intervention, money, sterilisation, emerging markets

JEL No.: $\quad$ E51, E52, F31, F33

\footnotetext{
\# This paper draws on two chapters of Sharmila Devadas' PhD thesis at the University of Nottingham. The views expressed in this paper, unless otherwise indicated, are those of the authors, and do not in any manner reflect the position of the Central Bank of Malaysia. The authors wish to thank an anonymous referee for helpful comments on an earlier version. Corresponding author: Prof. M.F. Bleaney, School of Economics, University of Nottingham, Nottingham NG7 2RD, UK. Tel. +441159515464; Fax +441159514159. E-mails: michael.bleaney@nottingham.ac.uk; sharmdas@ gmail.com.
} 


\section{Introduction}

Foreign exchange intervention and sterilisation have become topical in recent years as emerging market countries, which typically manage their exchange rates to a considerable degree, have accumulated foreign exchange reserves amidst increased financial integration (Aizenman and Glick, 2009). In the absence of sterilisation of the effects of inflows and outflows across the exchanges on the domestic stock of broad money, intervention has consequences for domestic monetary conditions. For example, the purchase of domestic assets by foreigners from the non-bank private sector leads to an increase in broad money. This occurs even if the domestic currency paid out by the central bank in buying foreign exchange is subsequently sterilised in the interbank money market through open market operations (OMOs), thus keeping reserve money relatively unchanged. In order for capital inflows (and intervention) to not have an impact on broad money, central bank assets must be sold directly to foreigners rather than banks. As such, without full sterilisation, there is a danger that any advantages in export competitiveness gained by managing the nominal exchange rate could be eroded through higher inflation. Furthermore, there is also the risk of financial imbalances developing, namely in the form of excessive growth in credit and asset prices. Previous empirical estimates such as those of Aizenman and Glick (2009) and Lavigne (2008) have suggested a high degree of sterilisation, which would imply that this is not a problem in practice. There is, however, an important caveat here: these studies have focused almost exclusively on reserve money.

This focus on reserve money stands in sharp contrast to the recent empirical literature emphasising the role of money in the macroeconomy, which stresses broad rather than narrow money (Assenmacher-Wesche and Gerlach, 2007; Bridges and Thomas, 2012; Gerlach, 2004; Ireland, 2004; Leeper and Roush, 2003). These papers demonstrate a long- 
run relationship between broad money and prices. The theoretical importance of money is discussed by Nelson (2008). This work suggests that it is important to investigate whether foreign exchange inflows affect broader measures of the money stock, and this is the main contribution of our paper. We find that, unlike reserve money, broad money is to a significant degree not sterilised against foreign exchange intervention, particularly in the longer run. The failure to sterilise broad money in the longer run may explain why Cardarelli et al. (2010, pp. 355), in their cross-country study of large net private capital inflows, conclude that "a policy of resistance to nominal appreciation has not generally been successful in preventing real appreciation, and has often been followed by a sharper reversal of capital inflows, especially when these inflows have persisted for a longer time." Our estimates of sterilisation derive from a regression-based approach that includes controls for demand factors. Some part of monetary growth is demand-driven, reflecting factors such as the growth in personal incomes and returns on alternative assets, and it is important to control for these effects.

We find that the accumulation of foreign exchange reserves feeds through significantly to broad money in the long run, which raises concerns about inflationary pressures and asset price bubbles. This pattern is fairly consistent across countries, and is not confined to those with particular balance-of-payments positions or other characteristics. In Asia, the effect of reserve accumulation on broad money growth has fallen since the 1990s.

The rest of this paper is organised as follows. Previous research is surveyed in Section Two. Section Three discusses the theoretical framework and choice of econometric methodology. Empirical results are presented in Section Four, and Section Five concludes. 


\section{Literature Review}

There have been various single-country studies of the effects of intervention on reserve money in emerging market economies either as the focal point or as a subcomponent of issues related to capital flows and reserve accumulation (e.g. Ouyang and Rajan, 2011; Ouyang et al., 2010). However, there exist only a few recent studies that cover a group of countries that cut across regions, as in Aizenman and Glick (2009), Cardarelli et al. (2010) and Lavigne (2008). The first covers nine countries, of which six are Asian economies and three are Latin American economies, while the second and third encompass 52 and 35 countries respectively. Methods differ across the three, with the latter two adopting comparatively simple approaches to analysis.

Aizenman and Glick (2009) adopt a static multivariate regression specification based on a simple version of the monetary approach to the balance of payments, and allow for real GDP and inflation as control variables. They estimate rolling 40-quarter regressions over the period 1994-2006. They find short-run sterilisation rates of close to $100 \%$, particularly in the later years. Cardarelli et al. (2010) estimate sterilisation rates separately for each country in each calendar year, by a simple bivariate regression on the twelve monthly observations. They do this for both reserve money and broad money, but focus on the former. Further details of their results are contained in Cardarelli et al. (2009) - the cross-country averages in their Figure 8 indicate current-month sterilisation rates of base money of about 0.6 in the average country, with no particular time trend since 1991. Neither study considers how differences in countries' monetary policy frameworks and choice of instruments such as reserve requirements may have affected their estimation results. Lavigne (2008) focuses on periods of sizeable accumulation of foreign exchange reserves in East Asia from 1990 to 1996 and from 2000 to 2006 . He takes into account the effect of reserve requirements, but 
uses straightforward ratios, essentially dividing the cumulative change in currency in circulation over the relevant years by the cumulative change in net foreign assets $(\triangle \mathrm{NFA})$. The estimated sterilisation ratios exceed 0.8 in most cases.

In contrast, there is a dearth of econometric analysis of the effects of foreign exchange intervention on broad money growth, which is potentially more important than reserve money as broad money relates directly to investment and borrowing decisions within an economy. Arguably the effects on reserve money are of significance only because they may feed through to broad money. Another limitation of existing research is that sometimes only current-quarter or even current-month effects are investigated. When countries persistently accumulate foreign exchange reserves, it is necessary to consider longer-run and indirect effects extending beyond the current month or quarter.

Our contribution is to provide a detailed analysis for a reasonably large and diverse group of 28 countries, with particular attention to intervention effects on broad money growth. Our approach allows us to disentangle short-run and long-run effects of intervention.

\section{Theoretical Framework and Econometric Methodology}

The conceptual framework for analysing the effects of intervention begins with the following identities for the determinants of reserve money (RM) and broad money (BM).

$\Delta \mathrm{RM}_{\mathrm{t}}=\Delta \mathrm{NDA}_{\mathrm{cb}, \mathrm{t}}+\Delta \mathrm{NFA}_{\mathrm{cb}, \mathrm{t}}$

where

$\Delta \mathrm{NDA}_{\mathrm{cb}, \mathrm{t}}=$ the change in net domestic assets of the central bank during time $\mathrm{t}$

$\Delta \mathrm{NFA}_{\mathrm{cb}, \mathrm{t}}=$ the change in net foreign assets of the central bank during time $\mathrm{t}$ 


$$
\Delta \mathrm{BM}_{\mathrm{t}}=\Delta \mathrm{NDA}_{\mathrm{cb}, \mathrm{t}}+\Delta \mathrm{NDA}_{\mathrm{bs}, \mathrm{t}}+\underbrace{\Delta \mathrm{NFA}_{\mathrm{cb}, \mathrm{t}}+\Delta \mathrm{NFA}_{\mathrm{bs}, \mathrm{t}}}_{\begin{array}{c}
\text { Related to the balance } \\
\text { of payments }
\end{array}}
$$

where

$\Delta \mathrm{NDA}_{\mathrm{bs}, \mathrm{t}}=$ the change in net domestic assets of banking institutions during time $\mathrm{t}$

$\Delta \mathrm{NFA}_{\mathrm{bs}, \mathrm{t}}=$ the change in net foreign assets of banking institutions during time $\mathrm{t}$

Narrow and broad sterilisation respectively involve insulating reserve money and broad money from changes in central bank NFA, for instance by carrying out OMOs. The identity (2) indicates that broad money growth is essentially driven by domestic credit creation and the balance of payments. Foreign exchange intervention is reflected in $\Delta \mathrm{NFA}_{\mathrm{cb}, \mathrm{t}}$. Marketbased sterilisation which absorbs liquidity from banks results in offsetting elements: a negative $\Delta \mathrm{NDA}_{\mathrm{cb}, \mathrm{t}}$ (the central bank borrows from banking institutions), and a positive $\triangle \mathrm{NDA}_{\mathrm{bs}, \mathrm{t}}$ (banking institutions lend to the central bank). Nevertheless, as the identity indicates, $\Delta \mathrm{NFA}_{\mathrm{cb}, \mathrm{t}}$ still has a direct impact on $\Delta \mathrm{BM}_{\mathrm{t}}$. This is because the balance of payments flows associated with the intervention are still allowed to permeate the financial system; a trade surplus, or foreigners' purchases of financial assets from residents, both result in higher deposits with banks. There are also possible indirect effects through credit creation as banking institutions can draw down the liquidity that was absorbed by the central bank, resulting in a rising money multiplier.

Some portion of the growth of the money supply is demand-driven, by growth in nominal incomes and the opportunity costs on alternative assets, for example. To make sure that our estimates of sterilisation are not distorted by this effect, we add controls for demand factors, as in Aizenman and Glick (2009). Thus the equation that we estimate for each country is of the form 


$$
\Delta \mathrm{BM}_{\mathrm{t}}=\mathrm{a}+\mathrm{b} \Delta \mathrm{NFA}_{\mathrm{t}}+\underline{\mathrm{c}} \cdot \underline{\mathrm{Z}}_{\mathrm{t}}+\mathrm{u}_{\mathrm{t}}
$$

where the vector $\underline{Z}$ consists of a set of control variables that are discussed in detail later; $a, b$ and the vector $\underline{c}$ are parameters to be estimated; and $u$ is a random error. The sterilization coefficient for country $j$ is estimated as $\left(1-b_{\mathrm{j}}\right)$. At the second stage we investigate whether the set of country estimates $\left(1-b_{\mathrm{j}}\right)$ is correlated with country characteristics such as the current account balance.

Net foreign assets are equal to gross foreign assets minus gross foreign liabilities. Gross foreign assets consist of foreign exchange reserves plus non-currency items such as gold stocks and Special Drawing Rights (SDRs). The gross assets and liabilities series are not always complete and may have been subject to changes in definition, for example with the shift to Standardised Reporting Forms. Moreover, recorded gross assets are occasionally smaller than foreign exchange reserves, which implies that non-currency assets are implausibly negative. In this paper we proxy changes in net foreign assets by changes in foreign exchange reserves, which we believe to be a more reliable series. Dominguez (2012) uses data on a component of the balance of payments statistics - the change in the US dollar value of reserve assets - as a measure of intervention. These figures are less complete than foreign exchange reserve data, but closely correlated with them (the median correlation coefficient across the 28 countries in our data set is 0.93 ).

Foreign currency reserves consist mostly of securities denominated in foreign currencies. The domestic-currency value of net foreign assets can therefore vary because of valuation effects of a given stock; these valuation effects do not correspond to any actual flow across the exchanges. Accurate estimation of the valuation effects requires full information on the composition of each country's foreign exchange reserves, which is very 
much lacking. The IMF's COFER database ${ }^{1}$ indicates that, aggregated over the whole world, US dollar (USD) assets dominate reserves, but to a decreasing extent - USD assets represented approximately $60 \%$ of reserves in 2010 compared with $75 \%$ over $1995-1998$. However, the currency composition is only known for a portion of reserves belonging to a segment of countries, and this portion, known as allocated reserves in the database, has dwindled over time.

In the absence of further information, we assume that foreign exchange reserves of each country consist $100 \%$ of US dollar assets. Since the data source gives reserves valued in US dollars, any change in this amount $\left(\Delta \mathrm{FXR}_{\mathrm{t}}^{\mathrm{USD}}\right)$ is assumed to represent a genuine flow. This ignores the component arising from interest payments on foreign securities, which Dominguez (2012) estimates to be about 4\% p.a. globally. Since interest payments are a very smooth series, this should make little difference to our results. This flow is translated into national currency at the average exchange rate prevailing during that period $\left(\mathrm{E}_{\mathrm{t}}^{\mathrm{avg}}\right.$ : national currency units per US dollar).

$$
\Delta \mathrm{FXR}_{\mathrm{t}}=\Delta \mathrm{FXR}_{\mathrm{t}}^{\mathrm{USD}} \cdot \mathrm{E}_{\mathrm{t}}^{\mathrm{avg}}
$$

Column (1) of Table 1 shows that the correlation between this measure of $\triangle \mathrm{NFA}$ and an unadjusted measure that is simply based on the change in the domestic-currency value of reserves over the period is sometimes quite low, particularly for countries that have had substantial exchange rate movements against the US dollar.

Column (2) of Table 1 contains the correlation coefficients between the change in the national currency value of foreign exchange reserves and the change in the national currency value of net foreign assets, both adjusted for exchange rate revaluation effects

\footnotetext{
${ }^{1}$ Source: http://www.imf.org/external/np/sta/cofer/eng/index.htm
} 
(Adjusted $\triangle \mathrm{FXR}_{\mathrm{t}}$ and Adjusted $\triangle \mathrm{NFA}_{\mathrm{t}}$ respectively). Low correlations would primarily reflect the difference in components between the two measures, with additional foreign assets and the netting off of foreign liabilities in the latter. The correlations are, however, fairly high across countries, with 20 countries exhibiting a correlation of more than 0.75 . There are notably low correlations for Japan and Canada, which we attribute to possible misclassification or reporting errors in the NFA series, since in the case of both countries FXR exceeds the gross foreign asset component of NFA several times over. 


\section{Table 1. Correlation between Different Measures of Foreign Exchange Intervention}

\begin{tabular}{|c|c|c|c|}
\hline \multirow{4}{*}{ Country } & \multicolumn{3}{|c|}{ Correlation Coefficient } \\
\hline & (1) & $(2)$ & \multirow{3}{*}{$\begin{array}{c}(3) \\
\Delta \text { FXR }_{\mathrm{t}}^{\mathrm{USD}} \\
\text { and } \\
\Delta \mathrm{RA}(\mathrm{BOP})_{\mathrm{t}}^{\mathrm{USD}} \\
1990 \mathrm{q} 1-2010 \mathrm{q} 2 \\
\end{array}$} \\
\hline & $\begin{array}{c}\text { Adjusted } \Delta F X R_{t} \\
\text { and } \\
\text { Unadjusted } \Delta \text { FXR }_{t}\end{array}$ & $\begin{array}{c}\text { Adjusted } \Delta \text { FXR }_{\mathrm{t}} \\
\text { and } \\
\text { Adjusted } \Delta \mathrm{NFA}_{\mathrm{t}}\end{array}$ & \\
\hline & \multicolumn{2}{|c|}{$1990 \mathrm{~m} 1-2010 \mathrm{~m} 6$} & \\
\hline Argentina & 0.81 & $0.79^{(\mathrm{a})}$ & 0.93 \\
\hline Australia & 0.93 & 0.58 & 0.98 \\
\hline Brazil & 0.49 & 0.69 & 0.98 \\
\hline Canada & 0.82 & 0.00 & 0.86 \\
\hline Chile & 0.67 & 0.97 & $0.95^{(\mathrm{b})}$ \\
\hline China & 0.98 & 0.71 & $0.99^{(\mathrm{c})}$ \\
\hline Colombia & 0.33 & 0.81 & $0.92^{(\mathrm{d})}$ \\
\hline Czech Rep & $0.37^{(\mathrm{e})}$ & $0.91^{(\mathrm{e})}$ & $0.78^{(\mathrm{f})}$ \\
\hline Denmark & 0.90 & 0.81 & 0.91 \\
\hline Hong Kong & $1.00^{(\mathrm{h})}$ & $0.71^{(\mathrm{h})}$ & $0.95^{(\mathrm{i})}$ \\
\hline Hungary & 0.66 & $0.76^{(\mathrm{j})}$ & 0.87 \\
\hline India & 0.72 & 0.87 & 0.83 \\
\hline Indonesia & 0.37 & 0.84 & 0.92 \\
\hline Israel & 0.75 & $1.00^{(\mathrm{k})}$ & 0.96 \\
\hline Japan & 0.29 & 0.16 & 0.94 \\
\hline Korea & 0.12 & 0.69 & 0.96 \\
\hline Malaysia & 0.88 & 0.76 & $0.95^{(\mathrm{l})}$ \\
\hline Mexico & 0.63 & 0.94 & 0.79 \\
\hline New Zealand & 0.85 & 0.93 & 0.98 \\
\hline Norway & 0.88 & $0.80^{(\mathrm{m})}$ & 0.64 \\
\hline Peru & 0.84 & 0.89 & 0.96 \\
\hline Philippines & 0.74 & 0.74 & 0.92 \\
\hline Poland & 0.48 & 0.85 & $0.93^{(\mathrm{n})}$ \\
\hline Russia & $0.58^{(\mathrm{o})}$ & $0.99^{(\mathrm{o})}$ & $0.98^{(\mathrm{p})}$ \\
\hline Singapore & 0.57 & 0.99 & $0.70^{(\mathrm{q})}$ \\
\hline South Africa & 0.02 & 0.78 & 0.89 \\
\hline Thailand & 0.68 & 0.93 & 0.95 \\
\hline Turkey & 0.36 & 0.81 & 0.92 \\
\hline
\end{tabular}

(1) The adjusted change in the national currency value of foreign exchange reserves which excludes exchange rate revaluation changes (Adjusted $\Delta \mathrm{FXR}_{\mathrm{t}}$ ) is equal to $\Delta \mathrm{FXR}_{\mathrm{t}}^{\mathrm{USD}} \cdot \mathrm{E}_{\mathrm{t}}^{\mathrm{avg}}$.

The unadjusted change in the national currency value of foreign exchange reserves which includes exchange rate revaluation changes (Unadjusted $\Delta \mathrm{FXR}_{\mathrm{t}}$ ) is equal to $\mathrm{FXR}_{\mathrm{t}}^{\mathrm{USD}}$. $\mathrm{E}_{\mathrm{t}}-\mathrm{FXR}_{\mathrm{t}-1}^{\mathrm{USD}} \cdot \mathrm{E}_{\mathrm{t}-1}$.

(2) The adjusted change in the national currency value of net foreign assets which excludes exchange rate revaluation changes (Adjusted $\triangle \mathrm{NFA}_{\mathrm{t}}$ ) is equal to $\mathrm{NFA}_{\mathrm{t}}-\mathrm{NFA}_{\mathrm{t}-1}\left(1+\frac{\Delta \mathrm{E}_{\mathrm{t}}}{\mathrm{E}_{\mathrm{t}-1}}\right)$.

(3) $\triangle \mathrm{RA}(\mathrm{BOP})_{t}^{\mathrm{USD}}$ is the change in reserve assets in USD taken from the balance of payments account and excludes exchange rate revaluation effects.

Unless otherwise indicated below, the correlation coefficients in (1) and (2) are based on monthly data over 1990m1-2010m6, and those in (3) are based on quarterly data over 1990q1-2010q2:

(a)1990m2-2010m6, (b)1991q1-2010q2, (c)Annual data, 1990-2009, (d)1996q1-2010q2, (e)1993m22010m6, (f)1993q2-2010q2, (g)Annual data, 1990-2009, (h)1997m1-2010m6, (i)1999q1-2010q2, (j)2000m1-2010m6, (k)1990m1-2010m5, (l)1999q1-2010q2, (m)1990m1-2010m4, (n)2000q1-2010q2, (o)1996m1-2010m6, (p)1996q1-2010q2, (q)1995q1-2010q2. 
In column (3) of Table 1, we present the correlation coefficients between the change in the USD value of foreign exchange reserves and the USD value of reserve assets flow from the balance of payments used by Dominguez (2012) $\left(\Delta \mathrm{FXR}_{\mathrm{t}}^{\mathrm{USD}}\right.$ and $\Delta \mathrm{RA}(\mathrm{BOP})_{\mathrm{t}}^{\mathrm{USD}}$ respectively). The latter includes the change in the stock of non-currency reserves, namely monetary gold, Special Drawing Rights (SDRs) and the reserve position with the IMF. The correlation coefficients serve as a check on the accuracy of the proxy for intervention that we have used. Low correlations can arise from differences in components, and importantly, if a substantial fraction of reserves is held in assets denominated in foreign currency other than the USD, from the exchange rate revaluation effects for which we have not made an adjustment. We find, however, that the correlation coefficients are relatively high across the countries, with 26 countries displaying a coefficient of more than 0.75 . The two exceptions are Norway and Singapore.

\section{Baseline Model Specification}

Individual country estimations are based on quarterly observations over the sample period $1990 \mathrm{q} 1$ to $2010 \mathrm{q} 2^{2}$. The sample is shorter for some countries because of the lack of availability of long time series data for certain variables. The following is the basic model for quarterly broad money growth:

\footnotetext{
${ }^{2}$ We utilise individual country regressions rather than panel data methods because it is our hypothesis that there are indeed differences in sterilisation coefficients across countries and we do not assume one particular type of relationship to hold. Basic fixed effects and random effects models have a limitation in that slope homogeneity is assumed for the cross section and over time.
} 


$$
\begin{aligned}
\Delta \mathrm{BM}_{\mathrm{t}} / \mathrm{BM}_{\mathrm{t}-1} & =\alpha_{0} \\
& +\sum_{\mathrm{i}=1}^{4} \alpha_{1 \mathrm{i}} \Delta \mathrm{BM}_{\mathrm{t}-\mathrm{i}} / \mathrm{BM}_{\mathrm{t}-\mathrm{i}-1}+\sum_{\mathrm{i}=0}^{4} \alpha_{2 \mathrm{i}} \Delta \mathrm{FXR}_{\mathrm{t}-\mathrm{i}} / \mathrm{BM}_{\mathrm{t}-\mathrm{i}-\mathrm{i}}+\sum_{\mathrm{i}=0}^{4} \alpha_{3 \mathrm{i}} \Delta \mathrm{Y}_{\mathrm{t}-\mathrm{i}} \\
& +\sum_{\mathrm{i}=0}^{4} \alpha_{4 \mathrm{i}} \Delta \mathrm{i}_{\mathrm{t}, \mathrm{i}}-\sum_{\mathrm{i}=0}^{4} \alpha_{5 \mathrm{i}} \Delta \mathrm{i}_{\mathrm{B}, \mathrm{t}-\mathrm{i}}-\sum_{\mathrm{i}=0}^{4} \alpha_{6 \mathrm{i}} \Delta \mathrm{i}_{\mathrm{US}, \mathrm{t}-\mathrm{i}}+\sum_{\mathrm{i}=0}^{4} \alpha_{7 \mathrm{i}} \Delta \ln (\mathrm{REER})_{\mathrm{t}-\mathrm{i}}-\sum_{\mathrm{i}=0}^{4} \alpha_{8 \mathrm{i}} \Delta \operatorname{Inf}_{\mathrm{t}-\mathrm{i}} \\
& + \text { seasonal dummies }+\varepsilon_{\mathrm{t}}
\end{aligned}
$$

where $B M$ is real broad money; $\triangle F X R$ is the adjusted measure of foreign exchange inflows, in real terms; $Y$ is the $\log$ of real GDP; $i_{\mathrm{M}}, i_{\mathrm{B}}$ and $i_{\mathrm{US}}$ are respectively the interest rates on money, bonds and US Treasury Bills; REER is the real effective exchange rate and Inf is the consumer price inflation rate. Four lags of each variable, including the dependent variable, are included. A similar equation is estimated for reserve money except that $i_{\mathrm{B}}$ is omitted. The control variables reflect standard money demand specifications: income, domestic interest rate differentials, ${ }^{3}$ inflation and the return on holding foreign securities (captured by the foreign interest rate and exchange rate variables). The precise definition of variables is given in Appendix Table A1. The purpose of these variables is to account for changes in the money aggregates that are unrelated to intervention. In the case of the broad money equation, it is also to allow for the estimation of intervention effects above and beyond that which may be related to underlying money demand from the non-bank private sector.

\footnotetext{
${ }^{3}$ More than one interest rate is included to capture both money's own rate of return and the return on an alternative domestic asset (i.e. bonds). Theoretically, this is based on the portfolio balance model in which domestic assets are not perfect substitutes. We recognise that interest rates on money and bonds may, nevertheless, be highly correlated, which would result in large standard errors in their coefficients. In our sample of 28 countries, both interest rates enter the estimating equations for only ten countries (individually for eight and as a spread for two) due to data limitations. Correlations between the changes in the interest rates are mostly below 0.65 , and in our general to specific modeling, at least one domestic interest rate variable still enters the final equation for all the ten countries.
} 
Because of the lags in equation (5), the procedure generates both a short-run (currentquarter) and a long-run estimate of the sterilisation coefficient for each country $\left(1-b_{\mathrm{j}}\right)^{4}$. The short-run sterilisation coefficient is $\alpha_{20}$, and the long-run coefficient is:

$$
\alpha_{2, \mathrm{LR}}=\sum_{\mathrm{i}=0}^{4} \alpha_{2 \mathrm{i}} /\left(1-\sum_{\mathrm{i}=1}^{4} \alpha_{1 \mathrm{i}}\right)
$$

Equation (5) contains a large number of regressors, some of which are inevitably insignificant. To obtain a more parsimonious regression for each country, a general-tospecific modelling procedure was adopted. At each step the least significant variable was removed, and the equation re-estimated, until all the remaining regressors were statistically significant at the $10 \%$ level. Only the contemporaneous effect of the change in foreign exchange reserves was retained even if insignificant. Although the initial unrestricted model is identical, these parsimonious specifications differ across countries. A comparison of results from the parsimonious and the unrestricted regressions shows that the main effect of eliminating insignificant regressors is to reduce the standard errors of the sterilisation coefficients rather than to change the point estimate.

Reserve money is defined as the narrowest measure in each country, consisting of currency in circulation and banking institutions' reserve balances. Broad money is not defined identically across countries. In general, for each country, the broad money variable

\footnotetext{
${ }^{4}$ With regard to the potential endogeneity of $\triangle F X R$, Aizenman and Glick (2009) note that previous work did not find much effect from instrumental variable estimation on coefficient magnitudes and their standard errors. Furthermore, there are several mitigating factors: changes in $B M$ do not necessarily imply changes in monetary conditions that may affect $\triangle F X R$, and this is even more so since the latter is a policy variable that does not correspond exactly to movements in capital flows. The simultaneity bias also only applies to the contemporaneous effects of intervention and not its lagged effects, which we find is the stronger of the two in our results later.
} 
used here reflects the broadest national definition of money that is available, which excludes the central government and non-residents from the money-holding sectors ${ }^{5}$. Non-transferable deposits and securities other than shares account for the predominant portion of broad money components other than currency and demand deposits (IMF, 2000). National definitions of broad money may include repurchase agreements, negotiable certificates of deposits, commercial paper issued by depository corporations, bankers' acceptances, and depending on their liquidity, shares in money market funds. There will, therefore be, differences across countries in the range of financial assets considered as part of broad money.

None of the variables have been seasonally adjusted. This is to avoid the risk that seasonal adjustment affects the dynamics of the equations being estimated, resulting in a loss of information (Davidson and MacKinnon (1993) highlight the problem of biased coefficients arising from the use of linear filters when specifications have lags of the dependent variable). To account for seasonality, a set of seasonal dummy variables is included in the estimating equations. The effects of outliers, primarily in the context of non-normality in the residuals, and also in regard to other diagnostic test results, have been removed for some countries with the use of impulse dummy variables ${ }^{6}$.

The sample consists of the following 22 emerging market economies: China, Hong Kong, India, Indonesia, Korea, Malaysia, Philippines, Singapore, Thailand (Asia); Argentina, Brazil, Chile, Colombia, Mexico, Peru (Latin America); and Czech Republic, Hungary, Israel, Poland, Russia, South Africa and Turkey (others).

\footnotetext{
${ }^{5}$ The principal money-holding sectors are the same in almost all countries (IMF, 2000). Nevertheless, there may be some exceptions with regard to the classification of government units other than the central government, and non-residents.

${ }^{6}$ In instances where serial correlation and/or heteroscedasticity had been detected either in the unrestricted model or in the final parsimonious model, robust standard errors were used from the beginning of estimation. The robust standard errors were derived according to either the Newey-West HAC or White Consistent Covariances method. Serial correlation was tested for at lags 2, 4 and 8 using the F-test for joint significance of lagged residuals and the Breusch-Godfrey LM test.
} 
The focus is on these countries because of their tendency to intervene more in the foreign exchange market than the typical advanced countries. The requirement for quarterly data restricts the sample in some cases. To these we have added a number of smaller advanced countries for comparison purposes: Australia, Canada, Denmark, New Zealand and Norway. We have also included Japan because, like many other East Asian countries, it has accumulated a large stock of foreign exchange reserves in recent years.

\section{Empirical Results}

\subsection{Sterilisation of Reserve Money}

We start by estimating the parsimonious versions of equation (5) for reserve money. Table 2 shows the average short-run and long-run estimated coefficients of the change in foreign exchange reserves for emerging market economies by region, and for developed economies. The full array of country-by-country sterilisation coefficients is available from the authors upon request.

There are two columns of results in Table 2. Column (i) consists of the short-run coefficient on $\Delta \mathrm{FXR}_{\mathrm{t}} / \mathrm{RM}_{\mathrm{t}-1}$, while column (ii) lists the corresponding long-run coefficient. For the short-run coefficients, t-statistics are reported, while for the long-run coefficients, Fstatistics are reported - both statistics are in brackets.

The results indicate that the effect of foreign exchange intervention on reserve money growth is on average low. The average coefficients for the sample of 28 countries are 0.069 in the short-run and 0.095 in the long-run respectively. In effect, a one unit increase in foreign exchange reserves only leads to a 0.069 unit increase in the change in reserve money in the short run and a 0.095 unit increase in the long run. Thus, foreign exchange flows are more than $90 \%$ sterilised, even in the long run. However, the corresponding standard deviations across the sample group are 0.133 and 0.185 respectively, which suggests 
substantial dispersion across countries ${ }^{7}$. On closer inspection, the short-run and long-run coefficients are in the range of $0.000-0.200$ for about half of the countries (15 and 16 respectively), and negative in value for eight countries. Nevertheless, the negative coefficients tend to be of small economic significance, even if they are statistically significant. Since these results are fairly similar to those of Aizenman and Glick (2009), we now turn our attention to broad money.

\footnotetext{
${ }^{7}$ The coefficients on intervention effects may be higher for some countries than others due to the active use of reserve requirements, which lead to increases in reserve money. In the case of Hong Kong, which has a currency board arrangement, it would not be surprising if the coefficients on intervention effects are high. However, in our study, we have excluded Exchange Fund Bills and Notes (EFBNs), securities issued by the Hong Kong Monetary Authority (HKMA), from Hong Kong's measure of reserve money. Although not strictly functioning as sterilisation of intervention, these issuances do provide an avenue for banks to invest their surplus funds.
} 

Table 2. The Effects of a Change in Foreign Reserves
on Reserve Money Growth - Group Averages

\begin{tabular}{|c|c|c|}
\hline \multirow{3}{*}{ Group } & \multicolumn{2}{|c|}{$\begin{array}{c}\text { The group average effect of } \\
\Delta \mathrm{FXR}_{\mathrm{t}} / \mathrm{RM}_{\mathrm{t}-1} \text { on } \\
\Delta \mathrm{RM}_{\mathrm{t}} / \mathrm{RM}_{\mathrm{t}-1}\end{array}$} \\
\hline & (i) & (ii) \\
\hline & $\begin{array}{c}\text { Contemporaneous } \\
\beta_{20}\end{array}$ & $\begin{array}{l}\text { Long-run multiplier } \\
\beta_{2, \mathrm{LR}}=\sum_{\mathrm{i}=0}^{4} \beta_{2 \mathrm{i}} /\left(1-\sum_{\mathrm{i}=1}^{4} \beta_{1 \mathrm{i}}\right)\end{array}$ \\
\hline Asia & $\begin{array}{l}0.067 \\
(1.251)\end{array}$ & $\begin{array}{c}0.039 * * * \\
(9.170)\end{array}$ \\
\hline Latin America & $\begin{array}{c}0.050 \\
(1.113)\end{array}$ & $\begin{array}{l}0.111 * * * \\
(55.249)\end{array}$ \\
\hline Other Emerging Markets & $\begin{array}{l}0.104 * * * \\
(3.349)\end{array}$ & $\begin{array}{l}0.144 * * * \\
(20.947)\end{array}$ \\
\hline Developed Economies & $\begin{array}{c}0.048 \\
(0.466)\end{array}$ & $\begin{array}{l}0.106 \\
(1.900)\end{array}$ \\
\hline TOTAL & $\begin{array}{c}0.069 \\
(1.578)\end{array}$ & $\begin{array}{l}0.095 * * * \\
(20.430)\end{array}$ \\
\hline Sample standard deviation & 0.133 & 0.185 \\
\hline
\end{tabular}

- Column (i) reports the simple average of the contemporaneous effect and the corresponding average $t$-statistic.

- Column (ii) reports the simple average of the long-run multiplier and the corresponding average F-statistic, with the F-statistics taking the sign of the coefficient.

The F-statistic is for the test, $\sum_{\mathrm{i}=0}^{4} \beta_{2 \mathrm{i}} /\left(1-\sum_{\mathrm{i}=1}^{4} \beta_{1 \mathrm{i}}\right)=0$.

- For both $t$ - and F-statistics, ***: significant at 1\%; **: significant at $5 \%$; *: significant at $10 \%$.

- The results are based on restricted regressions, which include only statistically significant variables at the minimum $10 \%$ significance level. Regressors are removed one at a time in a unidirectional backwards manner based on the lowest $t$-statistic each time. This applies to all regressors except the contemporaneous effect of $\Delta \mathrm{FXR}_{\mathrm{t}} / \mathrm{RM}_{\mathrm{t}-1}$ which is not removed in the general to specific modelling process.

- Excluding Peru, for which the standard errors are particularly small, the average long-run effects are $0.107 * * *$ (14.180) for the Latin America sub-group and $0.088^{* * *}(11.536)$ for the whole sample. 


\subsection{Sterilisation of Broad Money}

In Table 3, we present the group averages of the short-run and long-run intervention effects on broad money growth, using equation (5). Individual country results are available from the authors upon request. As in the case of reserve money, the results refer to a parsimonious version of equation (5) that was the outcome of a general-to-specific modelling approach. As in Table 2, column (i) consists of the short-run coefficient on foreign exchange flows, while column (ii) lists the corresponding long-run coefficient.

The results shown in Table 3 indicate that the effect of intervention on broad money growth is, on average, relatively low in the short run, but noticeably higher in the long run. The average coefficients for the sample of 28 countries are 0.079 in the short run and 0.396 in the long run respectively. The short-run effects are not significant in the typical country, as shown by the average $t$-statistic, and are rather higher than the average of 0.079 only for Latin America. For countries with persistent inflows, the longer-run effects should be of more concern, and here the results are markedly different. A foreign exchange inflow that represents $1 \%$ of the broad money stock is estimated to increase broad money after four quarters by $0.47 \%$ in Asia, $0.34 \%$ in Latin America, $0.27 \%$ in other emerging markets, and $0.50 \%$ in developed economies. Thus there is a consistent pattern across all countries, and these numbers average out at $0.40 \%$ for the typical country, indicating only $60 \%$ sterilisation of broad money in the long run, compared with the $90 \%$ for reserve money shown in Table 2 . 

Table 3. The Effects of a Change in Foreign Reserves
on Broad Money Growth - Group Averages

\begin{tabular}{|c|c|c|}
\hline \multirow{3}{*}{ Group } & \multicolumn{2}{|c|}{$\begin{array}{c}\text { The group average effect of } \\
\Delta \mathrm{FXR}_{\mathrm{t}} / \mathrm{BM}_{\mathrm{t}-1} \text { on } \\
\Delta \mathrm{BM}_{\mathrm{t}} / \mathrm{BM}_{\mathrm{t}-1}\end{array}$} \\
\hline & (i) & (ii) \\
\hline & $\begin{array}{c}\text { Contemporaneous } \\
\alpha_{20}\end{array}$ & $\begin{array}{l}\text { Long-run multiplier } \\
\alpha_{2, \mathrm{LR}}=\sum_{i=0}^{4} \alpha_{2 \mathrm{i}} /\left(1-\sum_{\mathrm{i}=1}^{4} \alpha_{1 \mathrm{i}}\right)\end{array}$ \\
\hline Asia & $\begin{array}{l}0.096 \\
(1.077)\end{array}$ & $\begin{array}{c}0.466 * * \\
(4.187)\end{array}$ \\
\hline Latin America & $\begin{array}{c}0.239 * * * \\
(3.374)\end{array}$ & $\begin{array}{c}0.337 * * * \\
(17.855)\end{array}$ \\
\hline Other Emerging Markets & $\begin{array}{l}-0.069 \\
(-0.668)\end{array}$ & $\begin{array}{c}0.265^{* *} \\
(4.984)\end{array}$ \\
\hline Developed Economies & $\begin{array}{c}0.065 \\
(0.829)\end{array}$ & $\begin{array}{c}0.503 * * \\
(7.107)\end{array}$ \\
\hline TOTAL & $\begin{array}{c}\mathbf{0 . 0 7 9} \\
(\mathbf{1 . 0 8 0})\end{array}$ & $\begin{array}{c}\mathbf{0 . 3 9 6 * * *} \\
(\mathbf{7 . 7 1 5 )}\end{array}$ \\
\hline Sample standard deviation & 0.249 & 0.669 \\
\hline
\end{tabular}

- Column (i) reports the simple average of the contemporaneous effect and the corresponding average $t$-statistic.

- Column (ii) reports the simple average of the long-run multiplier and the corresponding average F-statistic, with the F-statistics taking the sign of the coefficient.

The F-statistic is for the test, $\sum_{\mathrm{i}=0}^{4} \alpha_{2 \mathrm{i}} /\left(1-\sum_{\mathrm{i}=1}^{4} \alpha_{1 \mathrm{i}}\right)=0$.

- For both $t$ - and F-statistics, ***: significant at 1\%; **: significant at 5\%;

*: significant at $10 \%$.

- The results are based on restricted regressions, which include only statistically significant variables at the minimum $10 \%$ significance level. Regressors are removed one at a time in a unidirectional backwards manner based on the lowest $t$-statistic each time. This applies to all regressors except the contemporaneous effect of $\Delta \mathrm{FXR}_{\mathrm{t}} / \mathrm{BM}_{\mathrm{t}-1}$ which is not removed in the general to specific modelling process. 
The corresponding standard deviations across the sample group of 28 countries are 0.249 and 0.669 respectively, which suggests substantial dispersion, particularly with regard to the long-run coefficients. The degree of dispersion is larger than for reserve money growth. On closer inspection, the short-run coefficients are in the range of $0.000-0.250$ for fourteen countries and negative in value for 10 countries. With regard to the long-run coefficients, seventeen countries fall in the range 0.200-0.750, whilst five countries display negative values.

It is difficult to make comparisons with the results of previous empirical work, not least because of the limited amount of existing research that has quantified the effects of intervention on broad money growth. Furthermore, where there has been work done, comparisons are complicated by differences in country coverage, methodology and sample period. Nevertheless, we have compared the long-run coefficients for a subset of countries ${ }^{8}$ analysed by Takagi (1999). Takagi's estimated coefficients are based on static multivariate regressions using quarterly data over the period 1987q1-1997q2. At an average of 0.428 for these countries, our result is markedly in contrast to that of Takagi's at -0.009 . Furthermore, on an individual-country basis, in Takagi's case, there is hardly any statistical significance of the coefficients, except in the case of the Philippines. One obvious difference between our study and Takagi's is the sample period under consideration, suggesting the importance of variations in the coefficients over time. However, it would appear that the methodology and data used also matter. With regard to the former, our dynamic model specification allows for both the contemporaneous and indirect effects of intervention to be taken into account.

Cardarelli et al. (2009) do not report the results for the effects of a change in foreign assets on changes in broad money, but they claim to find a high degree of sterilisation, as for

\footnotetext{
${ }^{8}$ The countries are Indonesia, Korea, Malaysia, Philippines and Thailand.
} 
reserve money. Since they estimate only a short-run coefficient, based on monthly data, their results are consistent with our findings.

\subsection{Estimated Sterilisation Coefficients and Country Characteristics}

Can the pattern of estimated sterilisation coefficients of broad money across countries be explained? This is the issue that we address in this sub-section. Initially, we test for differences among the countries in our sample by splitting them into clearly delineated groups based on regions, the nature of current account and capital account balances (surpluses versus deficits, commodity exporters versus importers), income levels (high income versus middle income) and monetary policy frameworks (inflation-targeting versus non-inflation-targeting). Table 4 shows that, based on the results of ANOVA F-tests for differences in means ${ }^{9}$, with the exception of a difference between commodity exporters and importers (and that only for the short-run sterilisation coefficients) none of the features are close to statistical significance.

In Table 5, we assess if there exist linear relationships between the long-run sterilisation coefficients and specific country characteristics. We treat the estimated coefficients for each country as the dependent variable, and use a series of bivariate regressions to investigate whether these coefficients vary systematically with (1) income levels; (2) the nature of intervention (volatility, the number of surplus periods, and reserve accumulation); (3) exchange rate flexibility; (4) financial sector development (with stock market capitalisation as a proxy) and (5) the nature of the current and capital accounts in terms of openness and net balances. As in Table 4, the results in Table 5 are resoundingly negative: in every case the $t$-statistic is very low and the adjusted R-squared negative. Thus

\footnotetext{
9 The distributions for the short-run and long-run coefficients were pre-tested for non-normality and heterogeneous variances across subgroups based on the subgroup classifications. We did not find any evidence of non-normality.
} 
we are left with the conclusion that no obvious features explain the degree to which broad money growth is sterilised. 


\section{Table 4. Mean Equality Tests for Intervention Effects on Broad Money Growth}

\begin{tabular}{|c|c|c|c|c|}
\hline \multirow[b]{3}{*}{ Groups } & \multicolumn{4}{|c|}{ Effect of $\Delta F X R$ on $\Delta B M$} \\
\hline & \multicolumn{2}{|c|}{ Short-run Coefficient } & \multicolumn{2}{|c|}{ Long-run Coefficient } \\
\hline & $\begin{array}{l}\text { Group } \\
\text { Mean }\end{array}$ & $\begin{array}{c}\text { Mean } \\
\text { Equality } \\
\text { F-test } \\
\text { (p-value) }\end{array}$ & $\begin{array}{l}\text { Group } \\
\text { Mean }\end{array}$ & $\begin{array}{c}\text { Mean } \\
\text { Equality } \\
\text { F-test } \\
\text { (p-value) }\end{array}$ \\
\hline $\begin{array}{ll}1 . & \text { Region } \\
\text { Asia } \\
\text { Latin America } \\
\text { Other EMEs } \\
\text { Developed Economies }\end{array}$ & $\begin{array}{l}0.096 \\
0.239 * * * \\
-0.069 \\
0.065\end{array}$ & 0.1681 & $\begin{array}{l}0.466 * * \\
0.337 * * * \\
0.265 * * \\
0.503 * *\end{array}$ & 0.9143 \\
\hline $\begin{array}{ll}\text { 2. } & \text { Current Account } \\
\text { Balance } \\
\text { CA surplus } \\
\text { CA deficit }\end{array}$ & $\begin{array}{l}0.114 * * \\
0.048\end{array}$ & 0.4929 & $\begin{array}{l}0.500^{* * *} \\
0.306^{* *}\end{array}$ & 0.4783 \\
\hline $\begin{array}{ll}3 . & \text { Commodity Exports } \\
\text { Net exporters } \\
\\
\text { Net importers }\end{array}$ & $\begin{array}{l}0.162 * * \\
-0.051\end{array}$ & $0.0237 * *$ & $\begin{array}{l}0.491 * * * \\
0.248^{* *}\end{array}$ & 0.3574 \\
\hline $\begin{array}{ll}4 . & \text { Capital Account } \\
\text { Balance } \\
\text { KA surplus } \\
\text { KA deficit }\end{array}$ & $\begin{array}{l}0.078 \\
0.082 *\end{array}$ & 0.9693 & $\begin{array}{l}0.432 * * * \\
0.307 * * *\end{array}$ & 0.6640 \\
\hline $\begin{array}{ll}5 . & \text { Income Level } \\
\text { High income } \\
\text { Middle income }\end{array}$ & $\begin{array}{l}0.031 \\
0.120^{*}\end{array}$ & 0.3510 & $\begin{array}{l}0.297 * * \\
0.481 * * *\end{array}$ & 0.4777 \\
\hline $\begin{array}{ll}6 . & \text { Monetary Policy } \\
& \text { Framework } \\
\text { Inflation-targeting } \\
\text { Non-inflation-targeting }\end{array}$ & $\begin{array}{l}0.064 \\
0.109 * *\end{array}$ & 0.6645 & $\begin{array}{l}0.429 * * \\
0.327 * * *\end{array}$ & 0.6519 \\
\hline
\end{tabular}

Current account and capital account surpluses are measured based on the number of surplus years as a proportion of the total number of years corresponding to the regression sample period for each country. A country is recorded as a surplus country if the proportion exceeds 0.5 .

The demarcation between commodity exporters and importers draws on data published in IMF (2012) which details cross country averages for net commodity exports/total exports based on yearly data over 1962-2010. Income level is measured by the average of GDP per capita based on purchasing power parity over the regression sample period for each country. Countries are classified as either high or middle income based on the World Bank income classification scheme.

Inflation-targeting countries are countries that have adopted the inflation-targeting framework at some point during our sample period.

Short-run and long-run average statistical significance of the coefficients for subgroups in the "Group Mean" columns are based on the corresponding simple average of $t$ - and F-statistics, with the F-statistics taking the sign of the coefficient. These do not indicate statistically significant differences across the subgroups.

The mean equality test is the single-factor ANOVA F-test or Welch F-test for unequal variances.

$* * *$ significant at the $1 \%$ level, **significant at the $5 \%$ level, *significant at the $10 \%$ level. 
Table 5. Bivariate Regressions between Long-run Coefficients of Intervention Effects and Country Characteristics

\begin{tabular}{|c|c|c|c|c|}
\hline & \multirow{2}{*}{$\begin{array}{c}\text { Country Characteristic } \\
\text { (Regressor in bivariate } \\
\text { regression) }\end{array}$} & \multicolumn{3}{|c|}{$\begin{array}{c}\text { Dependent Variable: } \\
\text { Long-run Effect of } \triangle F X R \text { on } \triangle B M\end{array}$} \\
\hline & & Coefficient & t-statistic & $\begin{array}{l}\text { Adjusted } \\
\mathbf{R}^{2}\end{array}$ \\
\hline 1. & GDP per capita & -2.526 & -0.209 & -0.04 \\
\hline 2. & Intervention volatility & 0.085 & 0.417 & -0.03 \\
\hline 3. & Surplus periods & -0.601 & -0.502 & -0.03 \\
\hline 4. & Reserve accumulation & 0.141 & 0.428 & -0.03 \\
\hline 5. & Exchange rate flexibility & -0.043 & -0.897 & -0.01 \\
\hline 6. & Stock market capitalisation & 0.001 & 0.624 & -0.02 \\
\hline 7. & Current account openness & 0.081 & 0.612 & -0.02 \\
\hline 8. & $\begin{array}{l}\text { Capital account openness } \\
\text { de-facto }\end{array}$ & 0.281 & 0.599 & -0.02 \\
\hline & de-jure (Chinn-Ito Index) & -0.046 & -0.104 & -0.04 \\
\hline 9. & Current account balance & 0.364 & 0.153 & -0.04 \\
\hline 10. & Current account surplus years & 0.089 & 0.246 & -0.04 \\
\hline & Capital account balance & 0.051 & 0.015 & -0.04 \\
\hline 12. & Capital account surplus years & -0.098 & -0.223 & -0.04 \\
\hline 13. & $\begin{array}{l}\text { Net direct and portfolio } \\
\text { investment balance }\end{array}$ & -0.577 & -0.161 & -0.04 \\
\hline 14. & $\begin{array}{l}\text { Net direct and portfolio } \\
\text { investment balance surplus } \\
\text { years }\end{array}$ & 0.076 & 0.158 & -0.04 \\
\hline 15. & Net other investment balance & -0.135 & -0.042 & -0.04 \\
\hline & $\begin{array}{l}\text { Net other investment balance } \\
\text { surplus years }\end{array}$ & -0.477 & -0.799 & -0.01 \\
\hline
\end{tabular}

The dependent variable is the set of estimated long-run multipliers for each country, which is available upon request.

Definition details of the country characteristics are provided in Appendix 2.

All regressions include a constant which is not shown for brevity.

For t-statistics, ***: significant at $1 \%$; **: significant at $5 \%$; $*$ : significant at $10 \%$. 


\subsection{Comparing the 1990s and the 2000s}

The 40-quarter rolling regressions shown in Aizenman and Glick (2009, Fig. 2) suggest that the degree of sterilisation of reserve money has increased over time in a number of Asian countries (China, Korea, Malaysia, Thailand), reaching close to $100 \%$ by the end of their sample period (2006). Lavigne's estimates (2008, Appendix B), comparing 2000-06 with 1990-96, suggest a marked increase in the sterilisation coefficient from low levels in China and India, but little change in Indonesia, Korea, Malaysia, Philippines, Singapore and Thailand, where the estimated sterilisation coefficient was already high in the earlier period. On the other hand, the average estimate in Cardarelli et al. (2009, Fig. 8) is fairly stable over time at around 0.6. Arguably persistent foreign exchange reserve accumulation since 2000 has made sterilisation a much more important issue in recent years.

To estimate whether the degree of sterilisation of broad money has changed between the 1990s and the 2000s, we split the sample into two periods: up to $1999 \mathrm{q} 4$, and from $2000 \mathrm{q} 1$ to 2010q2. The seasonal factors, all lagged $\Delta \mathrm{BM}_{\mathrm{t}-\mathrm{i}} / \mathrm{BM}_{\mathrm{t}-\mathrm{i}-1}$ variables, all $\Delta \mathrm{FXR}_{\mathrm{t}-\mathrm{i}} / \mathrm{BM}_{\mathrm{t}-\mathrm{i}-1}$ variables (contemporaneous and lagged values) and the intercept term are individually interacted with a dummy variable, $\mathrm{d}(00 \mathrm{q} 1-10 \mathrm{q} 2)$, that takes the value of 1 from $2000 \mathrm{q} 1$ 2010q2 and 0 otherwise, but to preserve degrees of freedom the coefficients of the other variables are constrained to be unchanged over the two sub-samples. The new estimating equation, in its general form, is as follows (but, rather than repeat the whole general-tospecific procedure, we just added the new variables into the chosen parsimonious regression for each country): 


$$
\begin{aligned}
\Delta \mathrm{BM}_{\mathrm{t}} / \mathrm{BM}_{\mathrm{t}-1}= & \alpha_{0}+\mathrm{d}(00 \mathrm{q} 1-10 \mathrm{q} 2) \\
& +\sum_{\mathrm{i}=1}^{4} \alpha_{1 \mathrm{i}} \Delta \mathrm{BM}_{\mathrm{t}-\mathrm{i}} / \mathrm{BM}_{\mathrm{t}-\mathrm{i}-1}+\sum_{\mathrm{i}=1}^{4} \alpha_{2 \mathrm{i}} \Delta \mathrm{BM}_{\mathrm{t}-\mathrm{i}} / \mathrm{BM}_{\mathrm{t}-\mathrm{i}-1} * \mathrm{~d}(00 \mathrm{q} 1-10 \mathrm{q} 2) \\
& +\sum_{\mathrm{i}=0}^{4} \alpha_{3 \mathrm{i}} \Delta \mathrm{FXR}_{\mathrm{t}-\mathrm{i}} / \mathrm{BM}_{\mathrm{t}-\mathrm{i}-1}+\sum_{\mathrm{i}=0}^{4} \alpha_{4 \mathrm{i}} \Delta \mathrm{FXR}_{\mathrm{t}-\mathrm{i}} / \mathrm{BM}_{\mathrm{t}-\mathrm{i}-1} * \mathrm{~d}(00 \mathrm{q} 1-10 \mathrm{q} 2) \\
& +\sum_{\mathrm{i}=0}^{4} \alpha_{5 \mathrm{i}} \Delta \mathrm{Y}_{\mathrm{t}-\mathrm{i}} \\
& + \text { seasonal dummies }+\mathrm{i}_{\mathrm{t}-\mathrm{i}}-\sum_{\mathrm{i}=0}^{4} \alpha_{7 \mathrm{i}} \Delta \mathrm{i}_{\mathrm{B}, \mathrm{t}-\mathrm{i}}-\sum_{\mathrm{i}=0}^{4} \alpha_{8 \mathrm{i}} \Delta \mathrm{i}_{\mathrm{US}, \mathrm{t}-\mathrm{i}}+\sum_{\mathrm{i}=0}^{4} \alpha_{9 \mathrm{i}} \Delta \ln (\mathrm{REER})_{\mathrm{t}-\mathrm{i}}-\sum_{\mathrm{i}=0}^{4} \alpha_{10 \mathrm{i}} \Delta \operatorname{Inf}_{\mathrm{t}-\mathrm{i}}
\end{aligned}
$$

The short-run coefficients on intervention effects are now $\alpha_{30}$ for the period from the beginning of the sample to $1999 \mathrm{q} 4$ and $\left(\alpha_{30}+\alpha_{40}\right)$ for the period $2000 \mathrm{q} 1-2000 \mathrm{q} 2$. The longrun coefficients are now:

$$
\begin{aligned}
& \alpha_{3, \mathrm{LR}}=\sum_{\mathrm{i}=0}^{4} \alpha_{3 \mathrm{i}} /\left(1-\sum_{\mathrm{i}=1}^{4} \alpha_{1 \mathrm{i}}\right): \text { sample start }-1999 \mathrm{q} 4 \\
& \alpha_{(3+4), \mathrm{LR}}=\left(\sum_{\mathrm{i}=0}^{4} \alpha_{3 \mathrm{i}}+\alpha_{4 \mathrm{i}}\right) /\left(1-\sum_{\mathrm{i}=1}^{4} \alpha_{1 \mathrm{i}}+\alpha_{2 \mathrm{i}}\right): 2000 \mathrm{q} 1-2010 \mathrm{q} 2
\end{aligned}
$$

Table 6 summarizes the results by region, which indicate that, for Asian countries in particular, the intervention effects are lower in the 2000q1-2010q2 period, indicating a significantly higher degree of sterilisation. For the average Asian country the long-run intervention coefficient for broad money has fallen from 0.89 to 0.28 ; for Latin America the figures are 0.28 for the $1990 \mathrm{~s}$ and 0.24 for the 2000s; and for the other emerging markets 0.03 for the $1990 \mathrm{~s}$ and 0.14 for the 2000s. For the whole sample the average has fallen from 0.43 to 0.22 . 
Table 6. The Effects of a Change in Foreign Reserves on Broad Money Growth - Group Averages for Sub-periods

\begin{tabular}{l|l|l|l|l}
\hline \multirow{2}{*}{ Country } & \multicolumn{4}{|c}{ The estimated effect of $\Delta \mathrm{FXR}_{\mathrm{t}} / \mathrm{BM}_{\mathrm{t}-1}$} \\
\cline { 2 - 5 } on $\Delta \mathrm{BM}_{\mathrm{t}} / \mathrm{BM}_{\mathrm{t}-1}$
\end{tabular}

- To split the periods, the constant, seasonal factors, all lagged $\Delta \mathrm{BM}_{\mathrm{t}-\mathrm{i}} / \mathrm{BM}_{\mathrm{t}-\mathrm{i}-1}$ variables, and all $\Delta \mathrm{FXR} \mathrm{R}_{\mathrm{t}-\mathrm{i}} / \mathrm{BM}_{\mathrm{t}-\mathrm{i}-1}$ variables (contemporaneous and lagged values) are individually interacted with a dummy variable that takes the value of 1 from 2000q1-2010q2 and 0 otherwise. See equation (8).

- Columns one and two report the respective group average contemporaneous effect for the two periods and the corresponding average $t$ - and F-statistics in brackets, with the F-statistics taking the sign of the coefficient. Columns three and four report the average long-run effects and corresponding average F-statistics.

- For both $t$ - and F-statistics, ***: significant at 1\%; **: significant at 5\%; *: significant at $10 \%$. 


\section{Conclusions}

In this paper, we set out to investigate the effects of real intervention on the growth of reserve money and broad money over the period 1990q1-2010q2. Empirical work in this regard has been relatively scarce, with emphasis mainly on reserve money sterilisation.

Our empirical analysis was carried out using multivariate dynamic regressions for a sample of 28 countries. This allowed us to consider the short-run and long-run effects of intervention on money growth separately and also to recognise heterogeneity across countries. For reserve money our results confirmed those of others: there is a high degree of sterilisation in both the short and the long run. For broad money our results were rather different: in the long run it is only about $60 \%$ sterilised, compared with over $90 \%$ in the short run. We investigated in some detail whether the estimated degree of long-run sterilisation of broad money varied systematically with country characteristics, including the structure of current and capital account balances, with negative results. Our findings imply that countries are substantially less successful at sterilising foreign exchange inflows than previous research has suggested. Although Asian countries seem to have insulated broad money from the effects of foreign exchange intervention more effectively since 2000 than previously, our point estimate for this period is that over $20 \%$ of foreign exchange reserve accumulation finds its way into the broad money stock, which still represents a substantial contribution to monetary growth, given the quantity of reserves accumulated. The fact that intervention impacts on broad money, particularly through lagged effects, raises some concern as it means that the capital inflows and increase in domestic liquidity associated with the intervention have permeated the financial system, influencing asset prices and credit creation. As such, policymakers may not have as much control over domestic monetary conditions as might be suggested by the full sterilisation of reserve money. In fact, it remains a concern that while 
excessive exchange rate volatility and loss of competitiveness may have been somewhat mitigated, the risks of financial imbalances and inflationary pressures remain.

\section{References}

Aizenman, J. and Glick, R. (2009), "Sterilization, Monetary Policy and Global Financial Integration", Review of International Economics, Vol. 17(4), pages 777-801.

Assenmacher-Wesche, K. And Gerlach, S. (2007), "Money at Low Frequencies", Journal of European Economic Association, Vol. 5(2-3), pages 534-542.

Bridges, J. and Thomas, R. (2012), "The impact of QE on the UK economy - some supportive monetarist arithmetic", Bank of England Working Paper, No. 442.

Cardarelli, R., Elekdag, S. and Ayhan Kose, M. (2010), "Capital Inflows: Macroeconomic Implications and Policy Responses", Economic Systems, Volume 34 (4), pages 333-356.

Implications and Policy Responses”, IMF Working Paper 09/40.

(2009), “Capital Inflows: Macroeconomic

Chinn, M. D. and Ito, H. (2006), "What Matters for Financial Development? Capital Controls,

Institutions, and Interactions," Journal of Development Economics, Volume 81, Issue 1, Pages 163 -

192 (October).

Davidson, R. and McKinnon, J.G. (1993), Estimation and Inference in Econometrics, Oxford: Oxford University Press.

Dominguez, K.M.E. (2012), "Foreign reserve management during the global financial crisis", Journal of International Money and Finance, Vol. 31, pp. 2017-2037.

Gerlach, S. (2004), “The Two Pillars of the European Central Bank”, Economic Policy 40, pages 389439.

Ilzetzki, E., Reinhart, C.M., and Rogoff, K.S. (2011) "Exchange Rate Arrangements Entering the 21st Century: Which Anchor Will Hold?" mimeo, March. Available via the Internet: http://personal.lse.ac.uk/ilzetzki/data/ERA-Country_Chronologies_2011.pdf.

International Monetary Fund (2000), "Monetary and Financial Statistics Manual”, Washington D.C.: International Monetary Fund.

(2012), "Commodity Price Swings and Commodity Exporters" Chapter 4 in the World Economic Outlook, April.

Ireland, P.N. (2004), "Money's Role in the Monetary Business Cycle," Journal of Money, Credit and Banking, Vol. 36(6), December, pages 969-983.

Lavigne, R. (2008), "Sterilized Intervention in Emerging Market Economies: Trends, Costs and Risks", Bank of Canada Discussion Paper. 
Leeper, E. and Roush, J. (2003), "Putting M back in Monetary Policy", Journal of Money, Credit and Banking, Vol. 35, pages 1217-1256.

Nelson, E. (2008), "Why Money Growth Determines Inflation in the Long Run: Answering the Woodford Critique", Journal of Money, Credit and Banking, Vol. 40 (8), pages 1791-1814.

Ouyang, A.Y. and Rajan, R.S. (2011), "Reserve accumulation and monetary sterilization in Singapore and Taiwan", Applied Economics, Vol. 43, pages 2015-2031.

Ouyang, A.Y., Rajan, R.S. and Willett, T.D. (2010), "China as a reserves sink: The evidence from offset and sterilization coefficients", Journal of International Money and Finance, Vol. 29, pages 951-972.

Takagi, S. (1999), "Sterilization and the Capital Inflow Problem in East Asia, 1987-1997", Discussion Paper No. 86, Economic Research Institute, Economic Planning Agency, Tokyo, Japan, August. 


\section{Appendix Table A1: General Explanatory Notes on Variables}

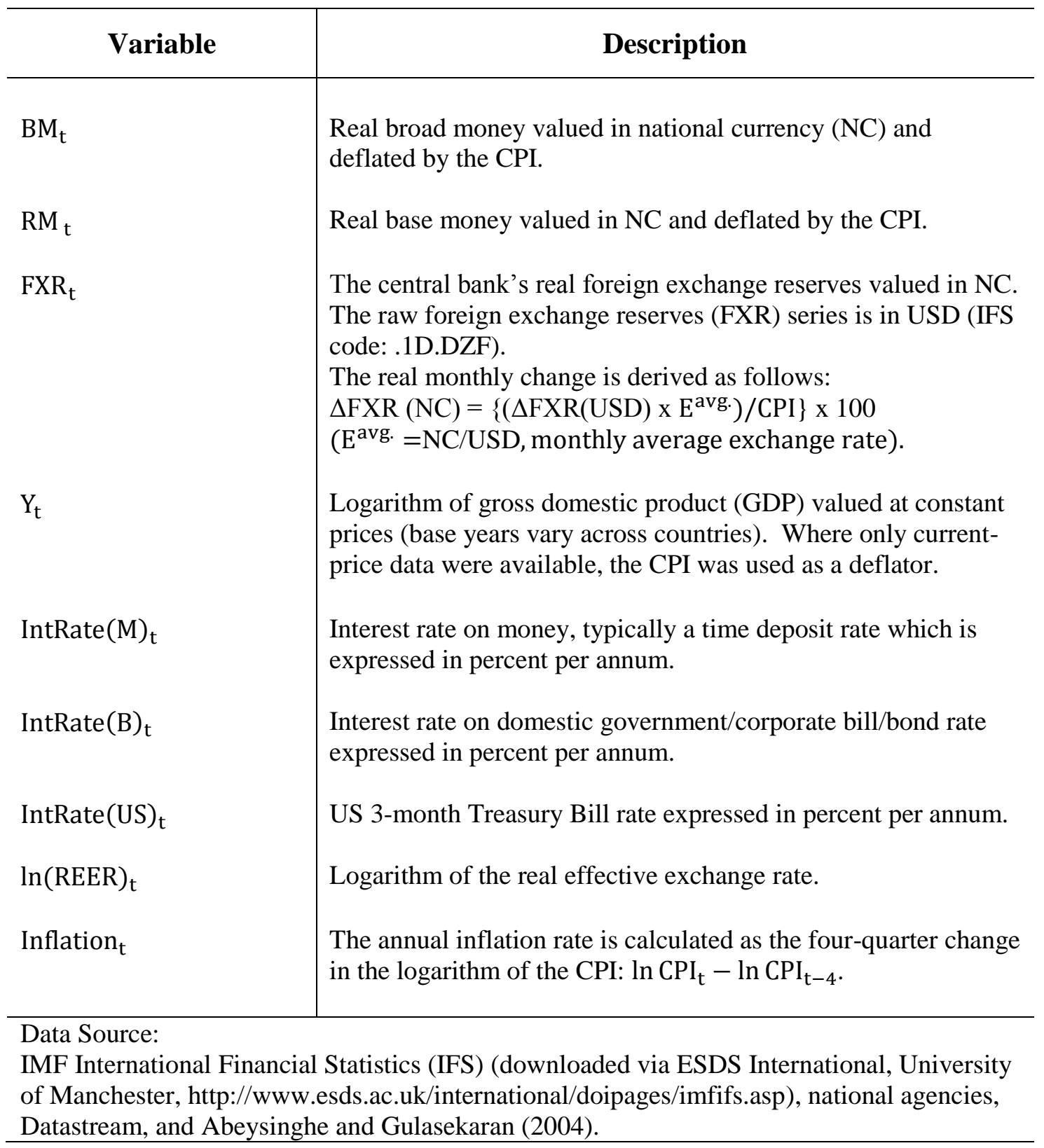




\section{Appendix 2: Definitions of Country Characteristics}

1. GDP per capita based on purchasing power parity (millions of current international dollar), is taken as an annual average over the regression sample period. Source: WEO. Countries are classified into high or middle income countries based on the World Bank income group classifications. (http://data.worldbank.org/about/countryclassifications)

2. Intervention volatility is measured by the standard deviation of the monthly changes in foreign exchange reserves scaled by the average annual nominal GDP.

3. Surplus periods is the number of quarters with a positive increase in reserves as a proportion of the total number of quarters.

4. Reserve accumulation is the sum of change in foreign exchange reserves, scaled by the average annual nominal GDP.

5. Exchange rate flexibility is identified based on the historical de facto fine classification provided by Ilzetzki et al. (2011). Each year's regime is assigned a number between 1 and 14, with larger numbers reflecting increased flexibility. We use the average over the years corresponding to the regression sample period as an indicator of each country's exchange rate regime flexibility. (http://personal.Ise.ac.uk/ilzetzki/IRRBack.htm)

6. Stock market capitalisation is the total value of all listed shares in a stock market as a percentage of GDP. Source: Global Financial Development Database (GFDD), The World Bank.

\section{Current account/Capital account openness:}

Average of the sum of the absolute value of annual inflows and outflows for each account respectively, taken as a ratio to average annual GDP. For de-jure capital account openness, the Chinn-Ito Financial Openness Index is averaged for each country.

\section{Current account/Capital account balance:}

Average of the annual net position in the account scaled by the average annual nominal GDP for the years that corresponds to the regression sample period, multiplied by 100 . Net direct and portfolio investment/other investment balance are calculated in a similar manner.

\section{Current account/Capital account surplus years:}

Number of years with net inflows into the account as a proportion of the total number of years that corresponds to the regression sample period. A country is recorded as a surplus country in the respective account if the ratio exceeds 0.5 . Net direct and 
portfolio investment/other investment balance surplus years are calculated in a similar manner. 